\title{
Anne Rutherford
}

\section{Film, trauma és az enunciatív jelen}

\begin{abstract}
Absztrakt
A traumakutatások azon kísérlete, hogy az atrocitásokról részletes beszámolót adjon, kudarcra van ítélve a trauma kimondhatatlan és elképzelhetetlen jellege miatt, ami a tapasztalat és a nyelv közti szakadékra is rámutat. Ez a megközelítés ugyanakkor a túlélôk fájdalma iránt is érzéketlen, akiket a közönség tagjaiként újra traumatizálhat a beszámoló. A tanulmány a traumával való munka alternatív lehetôségeire mutat rá, melyeknek alapja az etikai megközelítés, a túlélôk iránti törôdés, a reprezentáció többszólamú formái és az érzéki és affektív eszközökön keresztül a karakterekhez való érzelmi ragaszkodás. Ezek a verbalitáson kívüli lehetôségek a nézôket más szinten vonják be, és a megtestesült, érzéki és/vagy affektív élményen keresztül hoznak létre elköteleződést. A tanulmány két filmet elemez. A Bashu, a kis idegen (Bahram Beyzai, 1986) fikciója a gyerekszereplốn keresztül állítja munkába a szomatikus regisztert. A Puisi Tak Terkuburkan (Garin Nugroho, 1999) stilizált indonéz dokumentumfilmben a túlélố egyszerre színész és tanú, a hagyományos, énekelt vers és az újrajátszás által teszi összetettebbé a nézô tapasztalatát.
\end{abstract}

\section{Szerzô}

Anne Rutherford egyetemi adjunktus, a Nyugat-Sydney Egyetem Társadalomtudományi és Kommunikációs Iskolájában (School of Humanities and Communiation Arts) tanít filmtudományt. Könyve - What Makes a Film Tick? Cinematic Affect, Materiality and Mimetic Innervation (Peter Lang, 2011) - azt vizsgálja, hogy a filmes munkákban való affektív megmerítkezés milyen módokon teremt kapcsolatot a nézô és a történelem, az emlékezet és a kulturális sajátosságok között. Számos publikált esszéjének, interjújának és kreatív munkájának témája a filmes affektus és a megtestesülés, az esztétika, a mise-en-scène, a filmhang, a dokumentumfilm és az „animált gondolat” az etnográfiai fényképezésben. Több rövidfilmet is készített. Jelenlegi kutatása a mozi és az építészeti tér viszonyát vizsgálja az installációkban.

https://doi.org/10.31176/apertura.2019.15.3.1 


\section{Anne Rutherford}

\section{Film, trauma és az enunciatív jelen}

\section{Prológus: Csend és beszéd}

A traumafeldolgozásokon két, látszólag hasonló, valójában kifejezetten ellentétes tendencia fut végig búvópatakként: az elsô az ismétlés, a második a beszámolás kényszere.

Az ismétlés kényszere a trauma gyakran dokumentált utóhatása - a trauma átélóje újra és újra végigmegy a traumatikus helyzet minden apró részletén. A traumatikus emlék élénk továbbélése a túlélôi helyzetekben fellépő, rendkívül felfokozott jelenléttel függ össze, amely nyilván az adrenalinmechanizmusra adott hormonválasz következtében mélyen bevésődik vegetatív idegrendszerünkbe. Az ehhez kötődô ismétlési kényszer magában hordozza a kudarc tudatát. A túlélố beleveszik az esemény részleteibe, az ismétléssel megpróbálja megérteni a traumatikus pillanatban bekövetkezett törés mibenlétét és azt valahogy orvosolni, ám a részletek és a tényleges történés közötti hasadék aláássa e kísérleteket. ${ }^{[1]}$ Az ilyen ismétlés belsejében csend honol.

A beszámolás kényszere a traumától egy lépéssel távolabb lévôknél jelentkezik, akik a történtek megértésére törekednek, ám ezt a kényszert is ugyanaz a kudarc kíséri. Az ô kudarcuk azonban nem annak a tudatából ered, hogy az elbeszélés soha nem képes igazán megragadni a trauma természetét, hanem a várakozásból, hogy az „eset tényeivel” való szembenézés majd elvezet a megértéshez. E beszámolókban gyakran nagy hangsúlyt helyeznek a tanúságtétel fontosságára, a megtörtént borzalmakat aprólékosan részletezô, csapást csapás után soroló elbeszélésre.

A fenti, egymásnak ellentmondó indítékok mögött a tudás kérdésével szorosan összefüggố paradoxon húzódik. A súlyos trauma és a vele járó „kimondhatatlanság” alapvetô jellemzője, hogy amit a túlélô tud, senkinek sem szabadna tudnia; az ilyen tudás széttépheti a társadalom szövetét, az ember saját testében pedig megrepesztheti a létezés alapvető egzisztenciális talapzatát. A traumatikus események a létezés integritását pontosan a testben támadják meg, s ezzel összezúznak valamit, aminek a létérôl semmit sem tudtunk mindaddig, amíg el nem veszítettük. A trauma összetör valamit, ami emberi létünknek annyira alapvetô része, hogy egyáltalán fel sem fogjuk, amíg meg nem semmisült. ${ }^{[2]}$ Ha megkíséreljük leírni a találkozást saját megsemmisülésünkkel, fogalmi szókincsünk korlátai miatt már eleve elakadunk a ki- és mibenlétünkrôl való gondolatok megfogalmazásánál. Megpróbálhatjuk úgy megragadni mint egy egzisztenciális szakadékkal való szembesülést, de az „egzisztencia” filozófiai fogalom, melynek legtöbb megfogalmazása nem terjed ki a tapasztalat teljes szomatikus mélységére. ${ }^{[3]}$ 
E paradoxon (mivel ilyen tudással egyetlen embernek sem szabadna rendelkeznie) abban rejlik, hogy a traumától egy lépéssel távolabb állók erkölcsi vagy politikai elköteleződésból meg akarják érteni, a róla szóló tudás megszerzésére törekszenek. A trauma „kimondhatatlanságának” kulcsa talán éppen ez az elviselhetetlen tudás. ${ }^{[4]}$ Ez felveti a kérdést: ha a tudást keresôk valóban, testi értelemben megértenék a trauma magját, nem kerülnének-e azzal maguk is annak kísérteties ölelésébe?

Az elméletek ezt a csendet gyakran szégyenként kezelik. A sok egyéb tényezô között persze szégyen is lehet; a trauma összetett, mint a hagymahéj, további rétegeket raknak rá a szociális dimenziók és az emlékezet által összehordott fájdalmas asszociációk. Ezeket a felgyúlt rezonanciákat vissza lehet fejteni, mint ahogy a hagyma héjait hántjuk le, mégis elófordulhat, hogy az eredeti megrázkódtatás fojtogató szorítása soha nem enyhül. Ha a traumát „a pszichikai pajzs áttöréseként" értelmezzük, akkor a súlyos trauma hatása, hogy a darabokat soha többé nem lehet egyesíteni, ahogy Humpty Dumptyt sem a mondókában. ${ }^{[5]}$ Ez nem azt jelenti, hogy a darabokat nem lehet újra integrálni; minden traumával foglalkozó munkának kétségkívül ezt kell célul kitúznie: a reményt, hogy a megrázkódtatás természetének konceptualizálásával a romokon át utat lehet találni a gyógyulás és az egyensúly felé. Ez a traumaelméletek tétje. Ennek meg nem értése súlyos esetben egyének, közösségek, sôt egész nemzetek roncsait hagyja magányosan küszködni, amikor csak saját túlélő ösztöneikre hagyatkozhatnak, vagy ami még rosszabb, a trauma „feloldására” irányuló, szakemberek által vezetett, hatástalan kísérletek után talán már fel is adták.

Maga a csend összetett, ugyanúgy együtt járhat a beszéd megtagadásával, mint az arra való képtelenséggel. Elôször is ott van a hallgató megóvásának a vágya; a beszélố úgy érezheti, hogy a beszéddel mintha fekáliával kenné be a hallgatóját, és itt jön be a képbe az undor - egyfajta tabu, a bemocskolás tilalma. Az elbeszélés megtagadása összefügghet azzal, hogy az illetô a traumatikus esemény képének befogadását tagadja meg, mintha a szavakba öntés olyan önkép birtokba vételét vagy az azzal való azonosulást jelentené, ami nem összeegyeztethetô a pszichikai túléléssel. Úgy érezheti, hogy ha ilyen képet rajzol magáról, azzal mintha felkérné a hallgatóját, hogy ilyen keretben lássa ôt. Itt játszik alapvetô szerepet a szégyen, és az ilyen képek elszigetelése, távol tartása védekezés ez ellen. A harmadik tényezô az állandóan jelen lévô újratraumatizálódás kérdése. Ennek veszélyét hordozza a közelség, melynek jellemzôje a félelem - ahogy a beszéd közelít a trauma magjához, exponenciálisan nô a félelem az eredeti, felfokozott jelenlét újraélésének a fenyegetésétôl. Laura Marks írt arról, hogy a nyelv adott esetben annyira közel kerül az eseményhez, hogy „szempillantás alatt belobbantja a testet öltött jelentést”. ${ }^{[6]} \mathrm{Az}$ esztétikában ez a törekvés kelti életre az alkotást, ez az affektív múvészi tevékenység szent Grálja. A traumánál ez a fekete lyuk, amely a beszéló beszippantásával fenyeget. 
Ebben áll a csend paradoxona. A trauma magjában lévô csend bizonyos értelemben szakralizálja is az eseményt, amivel elérhetetlenné teszi, s egyben megvédi minden vizsgálódástól, nehogyfeloldja a védôburkot alkotó szoros csomókat.

\section{Az enunciáció kérdése}

Mindezek mögött ott húzódik a nyelv és a tapasztalat - két egymással párhuzamos egyenes, legjobb esetben aszimptota ${ }^{[7]}$ - viszonyának kérdése. A kettô közötti eltérés teljesebb felismerése alapvetôen megváltoztatná a trauma értelmezését. Különösen érdekes itt az enunciatív aktusok összetettségének kérdése, amelyek többnyire alapul szolgálnak a trauma gyakorlati tanulmányozásának: ki a beszélő, ki a hallgató, és hogyan formálódnak meg a beszédaktusok?

Bár léteznek alapvetô, elsôdleges szövegek, amelyeket Dominick LaCapra kifejezésével „elsôdleges tanúk" írtak le vagy mondtak el - akik áldozatként/túlélőként szólalnak meg -, a diskurzus nagy része a „másodlagos tanú” szemszögéból jelenik meg. ${ }^{[8]}$ Bár LaCapra óv a feltevés ellen, hogy a másodlagos tanú „belakhatná” a traumatizált személy tapasztalatát ${ }^{[9]}$, sok ilyen munka az áldozat nevében szólal meg. Ezt bizonyos esetekben a halottak iránti kegyelet meg is követelheti, de az is elôfordulhat, hogy viszonylag reflektálatlanul szólalnak meg valaki más nevében, akirôl távolléte ellenére is feltételezhetô, hogy még él. A trauma-szakirodalom egy részében ez a pozíció önreflexív. Ann Kaplan írja: „A legtöbbünk a legtöbbször »másodlagos« pozícióból, és nem közvetlenül tapasztalja meg a traumát." ${ }^{[10]}$ A traumával való közvetett találkozásnak ez a leírása legalább számol saját előfeltevéseivel, ám a „mi”, amelynek a nevében és amelyhez beszél, a túlélôt természeténél fogva kizárja a hallgatók/nézők köréből (és a beszélőkéből is). [11]

Az előfeltevéssel, hogy „mi” - beszélők és hallgatók - másodlagos vagy harmadlagos tanúk vagyunk, elszigeteljük a diskurzust az elsődleges hivatkozási forrásoktól; ha ugyanis elismernénk, hogy a beszélók, hallgatók között lehetnek túlélók, akik számára a diskurzusnak tétje van, az automatikusan megnövelné az elszámoltathatóság szintjét. Egyrészt megítélhetik a beszéló által hangoztatott tudást vagy ismeretet, másrészt a túlélók jelenléte a hallgatóságban megköveteli, hogy egy etikusan elkötelezett beszéló figyeljen saját beszédének a dinamikájára. 
Amikor az atrocitás részletes leírása nem egyszerúen szenzációhajhász, önző célokat szolgáló híradásként jelenik meg - ahogy az a médiában/újságírásban megszokott -, a „tanúságtétel” fontosságát, az áldozatokkal/túlélôkkel való szolidaritás érzését, az atrocitás tényeivel való szembenézés bátorságát szokták felhozni a beszámolót igazoló erkölcsi érvként. Amikor másodlagos tanúk megpróbálják ezt a hallgatókkal/olvasókkal megértetni, a leírás - a tények, részletek, konkrétumok csapás csapás utáni elmesélése - elsôsorban retorikai stratégiaként szolgál ahhoz, hogy elgondolhatatlan eseményeket konkréttá és affektívvé tegyenek, hogy a traumát élôvé tegyék a másodlagos hallgató számára. Ugyanez a stratégia a túlélók körében nagyon is ellentétes fogadtatásra lelhet. A részletes elbeszélések önmagukban is erôs traumás asszociációkat válthatnak ki a túlélókben. ${ }^{[12]}$

Egyrészt semmilyen, nyelvre vagy akár magára a képre irányuló elemzés nem képes megragadni ezt a dinamikát, mivel a trauma konkrét alanyairól, konfigurációiról és az emlékezet változatosságáról van szó. Az érzéki emlékezet teljesen kiszámíthatatlan, bármikor feltörhet belôle egy traumás emlék a jelenbe. Ez lehet egy dallam, egy gesztus, egy szag, egy szó, a víz, a sötétség, egy történet, egy ajtó, a túz, egy helikopter... Ezt az alapvetố jellegzetességet nevezi LaCapra „a trauma utóéletének”. Másrészt pedig e kiszámíthatatlanság ellenére feltételezhetjük, hogy az atrocitásokról való közvetlen beszámoló rendkívül megterhelô lehet egyes traumatúlélôk számára. Különösen összetett, ahogy ez a folyamat a mediatizált kultúrában kibontakozik; a háborús és szexuális erôszakról szóló beszámolók, a közvetített képek mindent elborító jelenléte óriási hatással lehet a traumás emlék napi szintú újraírására az ilyen erốszakot megtapasztalt embereknél. [13]

A cenzúra nem tud megoldást adni erre a dilemmára, de a befogadó, etikus témakezelés, amely figyel erre a dinamikára és felismeri a hallgatók sokféleségét, egész más megközelítést igényelne. Ez kiindulhat abból a felismerésból, hogy az atrocitás tett, míg a trauma tapasztalat. Míg a tett leírható, a trauma tapasztalata „megoszthatatlan, hiába írják le”. ${ }^{[14]} \mathrm{Az}$ atrocitás részletes leírása összemossa a tapasztalatot a tettel, mintha a tett megmagyarázhatná a tapasztalatot, vagy a tapasztalat helyett állhatna, márpedig ezt semmiképpen sem tudja megtenni. Semmilyen részletgazdagság sem képes olyasvalamit megértetni valakivel, ami teljességgel kívül esik a korábbi tapasztalatai körén. Ez megköveteli annak elismerését, hogy van, amit nem lehet elmondani - a hiányosságokat, a kihagyásokat, a közlés lehetetlenségeit, részlegességét. Ez megkérdôjelezi a feltevést, hogy ami a nyelvben kimondható, az képes tudást előállítani, és a tapasztalatot elérhetôvé teszi a hallgató/nézô számára. Susan Sontag az elsôdleges tanúk tapasztalatáról írja:

Mi - vagyis mindenki, aki soha nem tapasztalt ahhoz hasonlót, amin [a túlélók] átmentek - nem értjük. Nem fogjuk fel. Egész egyszerúen elképzelni sem tudjuk, hogy milyen volt. Nem tudjuk elképzelni, hogy milyen borzalmas, milyen rémisztô volt; és hogy ez mennyire mindennapivá válik. Nem tudjuk megérteni, nem tudjuk elképzelni. Ezt érzi makacsul minden katona, minden újságíró és segélymunkás és független megfigyelő, aki átesett a tưzkeresztségen, és szerencsésen megúszta a halált, amely a közelben másokra 
lesújtott. És igazuk van. ${ }^{[15]}$

Miriam Marquez, a Pinochet rendszer kínzásainak túlélôje, saját közvetlen tapasztalatát kifejezetten összefüggésbe hozza az ilyen típusú elképzelhetetlen tudással:

Tudják, ezt teljes képtelenség, lehetetlenség közel vinni az Önök valóságához, ahhoz, amit eddig önmagukról, a világról megtudtak... Minden, amit az én világomról el tudnak képzelni... abban a percben porrá égett. [16]

Mennyivel lehetetlenebb megismerni Marquez és más túlélók tapasztalatát, akik nem pusztán tanúi voltak mások megerôszakolásának, hanem saját testük vált az erôszak célpontjává? Mennyivel mélyebb „a pszichikai pajzs áttörése”, amikor az ember saját teste nem menedék, nem támaszpont, nem páncél a törékeny szubjektivitás számára? ${ }^{[17]}$ Miért feltételezzük, hogy a nyelv képes közölni a test elleni támadás tapasztalatát, amely a szubjektivitás széttöredezését vagy szétesését okozhatja?

Sok túlélố elég jól képes beszélni a tapasztalatáról. Egymás között, az ôket sújtó tudással szembenézve gyakran mutatnak keménységet, rezilienciát, egyfajta komor ôszinteséget. Ahogy azonban Jill Bennett rámutat, ennek a tudásnak van „belsô” és „külsô” része. ${ }^{[18]}$ Lehet, hogy a túlélô tud beszélni a tényeket, eseményeket, részleteket tartalmazó külsô burokról, mint egy külsô tanú, de ami belül van, más ügy. Bennett szerint a traumával foglalkozó múvészeti alkotás célja, hogy „a külsô és a belsố részeket kapcsolatba hozza egymással”. ${ }^{[19]}$ Ez a törekvés - „a belülrôl való megszólalás" - alapjában különbözik azoknak a traumafeldolgozásoknak a céljától, amelyeket „másodlagos tanúk” pozíciójából és nekik címezve fogalmaznak meg.

Dominic LaCapra Claude Lanzmann monumentális dokumentumfilmjének, a Soának (Shoah, 1985) csontig hatoló elemzésében felfedi azt a dinamikát, ahogy egy túlélóból elốcsalogatják a részleteket azért, hogy affektív tapasztalatot nyújtsanak a nézônek, hogy a másodlagos vagy harmadlagos tanúkban megképzôdhessen a tudás, az empátia. ${ }^{[20]}$ Az egyik jelenetben Abraham Bomba, egy borbély beszél auschwitzi tapasztalatáról. Lanzmann addig noszogatja a túlélôt, hogy beszéljen, amíg megszúnik a távolságtartó közlés lehetôsége, és a traumás emlék jelenvalósága feltör a diskurzus felszínére. A tanúságtétel itt a történelem, nem pedig a túlélô érdekét szolgálja. Milyen utóhatása volt a fenti interjúnak Bombára nézve, és vajon hogyan reagál a többi túlélô, látva ezt a tolakodó kérdezési stílust? Ez a kérdés nem merül fel a tanúvallomás készítésekor, amelynek célja az empatikus elkötelezôdés megteremtése a nézókben mint „másodlagos tanúkban”. [21]

A kép kontextusában a reprezentáció etikája körüli viták ezidáig legtöbbször a „megmutatni vagy nem megmutatni” kérdése körül forogtak. ${ }^{[22]}$ Ezeket a vitákat már számtalanszor végigrágták mind különbözô munkákban, mind a dokumentumfilm elméleteiben. ${ }^{[23]}$ Azokban az esetekben, amikor a tárgyalás során a fókusz áthelyeződik az önmagában vett reprezentációról a 
reprezentáció és a nézôség kapcsolatára, a közvetített traumabeszámolók vagy -képek megtekintését vagy befogadását övezô dinamika vizsgálatára, gyakran felmerül a „másodlagos traumatizálódás” gondolata. Ez különösen akkor fordulhat elô, amikor az „empatikus trauma” megtapasztalását megpróbálják megkülönböztetni a túlélốk traumájától. ${ }^{[24]}$ A befogadás vizsgálata foglalkozott a tanúskodás összetett, ambivalens dinamikájával is - mit jelent etikus nézônek lenni, mihez kezdhet egy empatikus tanú az atrocitásról készült képek által közvetített információval és affektussal, és hogyan végezhetô el a képek feldolgozásához szükséges értelmezés feladata. ${ }^{[25]}$ Én itt nem önmagában a képekkel kívánok foglalkozni, nem is a megmutatás/nem megmutatás ellentétével, hanem a filmes affektus megértésével a traumákkal kapcsolatos munkákban, mégpedig az etikus témakezelés kontextusában.

\section{Beszéd és érzelem}

Egy mûsorban egy nô beszél arról a tapasztalatáról, amikor a fiát egy fán találta felakasztva. [26] Ahogy beszámolója a trauma pillanatához közelít, a hangja rekedt suttogássá halkul, a mondatok kibogozhatatlanná válnak, a teste megmerevedik. Nem tudjuk, mekkora erőfeszítést jelent neki, hogy ezeket a szavakat ki tudja mondani, de bizonyosan nem a trauma higgadt szavakba öntését látjuk. A szavak erôtlenek, csak utalnak a pillanatra, sejtetik azt, aztán leejtik a nô és a kérdezô közötti térbe. Lehet, hogy sok nézô közömbös marad e pillanat iránt, de akik ráhangolódtak a trauma dinamikájára, azokat ez a pillanat a beszéd körül súrúsödô intenzív érzések felismerésére készteti. A kommunikáció egy hiányon keresztül zajlik, amely a megértés szakadéka lehet. Kitapintható a kimondott szó és a megtestesült emlék közötti távolság. Az érzelem a hézagon és a képernyốn keresztül a nézôre nem a szavakon, hanem a szavakat megtöltố csendeken, valamint a hang, a tekintet, a gesztusok nem verbális regiszterein keresztül ragad rá. Tudatában vagyok annak, hogy ezekkel a szavakkal egy színészi elôadást, egy traumás emlék kamera számára színre vitt, stilizált megjelenítését is leírhattam volna, a fenti azonban nem beállított jelenet. Itt nem pusztán az affektív jelenlét performatív kódjainak alkalmazásáról van szó.

A nyelv bizonyos értelemben tabuba ütközik, határokat érzékel, amelyeket nem szabad átlépni. Ez jelzi a nyelv komplex kettôsségét. A nyelv mint reprezentáció helyettesíti a távol lévôt: valamilyen hiányt jelöl. A nyelv mint enunciáció elviselhetetlen jelenlétet hordozhat, teljességet ölthet magára, amelyet valamilyen rejtett affektív áramlás feszít, és azzal fenyeget, hogy áttöri a nyelv vagy a narratíva kontrollált struktúráit. Ez a nyelv ellentmondásos dialektikája.

Az affektus által nem jelölt beszéd, amelyet az enunciáció aktusai nem szakítanak szét, bizonyos értelemben megkönnyíti a nézô helyzetét. A disszociáció - az affektus elfojtása vagy védekező blokkolása - által megjelölt beszédben az érzékeny hallgató/nézô felismerheti ennek a hiánynak, a szakadék körül beszívódó energiának az érzetét. A tudományos munkákat olyannyira jellemzố személytelen beszéd azonban (amely eleve a szavak jelentố hatalmába vetett, feltételezett bizalmon, a diskurzus lineáris kibontakoztatásán, a traumáról mint történelmi vagy társadalmipszichikai jelenségrôl való érzelemmentes elmélkedésen nyugszik) gyakran nem a fenti 
energetikai dinamikán, hanem annak hiányán alapul, mintha a beszéd és a meghallása mereven el lennének szigetelve, és nem visszhangoznának a hallgató affektív testi emlékezetében.

A megértés hiánya nem csak a hallgató helyzetét könnyíti meg, hanem a beszélőét is: beszéd közben nem kell arra figyelnie, hogy a szavak szabadjára engedhetik ezeket a rejtett áramlásokat, és sértetlenül léphet tovább. Mintha bármit büntetlenül ki lehetne mondani.

Az előadó egy nyilvános elóadásban - a történések dokumentálása érdekében - egy gyermekkel szemben elkövetett borzalmas atrocitásról számol be. ${ }^{[27]}$ Semmilyen részlettôl nem kíméli a hallgatóságot. Hatásosan beszél, a közönséget a pillanathoz szögezi, mégis láthatólag könnyedén siklik át a következő témára. Alig öt perc múltán már kedélyesen csacsog. Hogyan lehetséges ez? Bennett ezt nevezi „a tanúság kudarcának” [28]. Az elôadó elvesztette annak érzékelését, hogy bizonyos dolgok más regiszterben léteznek, amit tiszteletben kellene tartani. Ha ezeket hétköznapi módon - a diskurzus „normál” regiszterében - közelítjük meg, az a dolog elfogadhatóságára utal, és tagadja, hogy különös gonddal kell vele bánni.

Terápiás kontextusban a terápiás kapcsolat „egzisztenciális elköteleződése” [29] alapvetô fontosságú egy olyan tér megteremtéséhez, ahol meg lehet kísérelni az érzelem és az enunciáció közötti hiány megszüntetését. Ahogy a traumáról való diskurzus a klinikai környezetból átkerül a történelem és közös emlékezet terébe, már nem az a legfontosabb, hogy a beszédet és annak meghallgatását a törôdés etikája iránti alapvetố tudatosság övezze. [30]

A tények képesek vibrálni, színeket, hangokat, szagokat, képeket közvetíteni. Ha ennek belátása nélkül beszélünk ezekről a tényekról, akkor semmit sem tudunk az enunciáció aktusáról, a nyelv és a megtapasztalás közötti eltérésrôl, és hogy a nyelvből milyen kiszámíthatatlan módon törhetnek elô szikrák, amelyek azután átugorhatnak ezen a hasadékon, és begyújthatják a traumatikus emlék gyufásdobozát.

Egy virág körül zümmögó rovar olyan színeket, árnyalatokat és kontrasztokat lát, amelyek az emberi szem számára teljességgel érzékelhetetlenek. Mi, emberek csak ultraibolya fénnyel tudjuk egy rovar érzékelési tapasztalatát szimulálni. Ahogy a rovar egy másképpen jelölt perceptuális világra van ráhangolva, a trauma túlélôje a nem érintettek számára érzékelhetetlen rezgéseket is felfog, melyek maradéka végighullámzik a pszichikai pajzs törésein.

Alejandra Canales $A$ Silence Full of Things (2005) címú dokumentumfilmjében Miriam Marquez traumatúlélố így fogalmazza meg ezt a felismerést:

A kínzást nem ismerô ember minden érzelem nélkül képes nézni a csuklyás, kinyújtott karú iraki férfi képét, mert nem ismeri a képhez kötôdô hangokat, szagokat. Ki tudja elképzelni ezt a borzalmat? Ezt a borzalmat senki sem tudja elképzelni. [31] 


\section{2. Érzelem, esztétika és trauma}

Jill Bennett a trauma és az esztétikai tevékenység közötti kapcsolat vizsgálatakor a fókuszt a

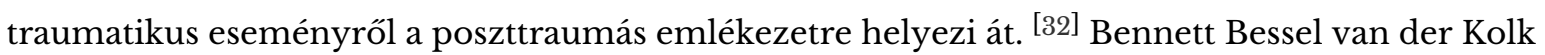
állítására hivatkozva - mely szerint „a traumatikus emlékezet »nem-deklaratív típusú«, és verbálisszemantikus-nyelvi reprezentáción kívül esố testi reakciókat is magában foglal” - azt állítja, hogy mind a narratív, mind a dokumentumfilmnek korlátai vannak, ugyanis mindkettô feltételezi a jelentés elsődlegességét és a szereplôvel való azonosulás fontosságát. ${ }^{[33]}$ Érvelése szerint a narratív film a karakterizáláson alapuló realista játékon nyugszik, a dokumentumfilmben pedig a szereplő „a tanúkat mondhatni egyfajta sajátos, rokonszenvezô kapcsolatra buzdítja”. [34]

Bertold Brecht, valamint LaCapra és más traumateoretikusok nyomán Bennett szót emel az olyan „durva empátia” [35] ellen, amely elmossa a határokat a traumatúléló tapasztalata és a nézók rokonszenvezố elkötelezôdése között. Idézi LaCapra felhívását az empátia olyan árnyaltabb, önreflexív formája mellett, amely felismeri és megtartja a különbségtételt „a reprezentációnak ellenálló trauma” és a nézôk tapasztalata között; amely elkerüli „a másik tapasztalatának az énhez való asszimilációját”. [36] Maga Bennett más megközelítést választ. Szerinte a szereplô és a közvetlen utalás hiánya megakadályoz mindenféle durva empátiát. Előnyösebbnek tartja az experimentális kortárs múvészet azon formáit, amelyek „a trauma lenyomatát [hordozzák]”, ám elkerülik mind a tanúságtétel politikáját, mind azt a realista feltételezést, mely szerint a múvészet képes „megragadni és átadni” a trauma tapasztalatát. ${ }^{[37]}$ Véleménye szerint ez a lenyomat az alkotás jelentést nem hordozó, affektív töltésében lakozik:

A múvészetben az affektus nem azon a szinten hat, hogy rokonszenvet kelt elôre meghatározott szereplók iránt; megvan a saját ereje [...]; túlmutat az olyan típusú erkölcsi érzelmek visszaigazolásán, amelyek egy meghatározott narratív helyzetre adott válaszokat alakítanak ki. [38]

Bennett az affektus - mint érzékelés által kiváltott intenzitás - deleuze-i hangsúlyú koncepcióját alkalmazza, és hangsúlyozza, hogy ellen kell állni az olyan múvészetnek, amely „inkább jelentést, mint testet" állít elō. ${ }^{[39]}$ Bennett szerint ez a szenzorikus intenzitás elóhívja a gondolatot, ami elvezet az anyaggal való kritikus kapcsolódáshoz, amely „komplexebb és gondolatibb, mint egy tisztán érzelmi vagy szentimentális reakció”. ${ }^{[40]}$ Ezt a kritikai esztétikai kapcsolódást „empatikus látásmódnak" nevezi. ${ }^{[41]}$ Bennett szerint

Deleuze elképzelésének értéke (mely szerint az affektusokat intenzitásként inkább formális eszközök, semmint a narratíva hozzák létre), hogy lehetôvé teszi, hogy az affektust ne a szereplôre adott érzelmi válaszként értsük, és így megoldást keressünk a narratív szerveződés korlátaira, amely az affektust bizonyos testi és erkölcsi határok közé 
szorítja. ${ }^{[42]}$

Bennett meggyôzőon érvel amellett, hogy az experimentális múvészet affektív találkozást hozhat létre, olyasvalaminek a szomatikus megtapasztalását, ami nincs megnevezve, de rögzíti „, trauma erejét”. ${ }^{[43]}$ Ezt „inkább tranzakciós mint kommunikatív jellegünek” írja le. ${ }^{[44]}$ Az érv azonban, mely szerint a narratívára adott válaszunk szükségszerúen a szereplôkhöz kötődô erkölcsi érzelemként jelenik meg, vagy abban benne foglaltatik, a narratíva igencsak korlátozott modelljére támaszkodik, valamint arra a feltevésre, hogy a narratív film egyértelmú. Mind a narratív játékfilm, mind a dokumentumfilm képes az affektív tapasztalatot a szereplö és az érzelem narrativizált bemutatásába olvasztani, viszont ennél sokkal rugalmasabb módokon is tudnak múködni. Ha ezt felismerjük, számos ígéretes lehetôség kínálkozik arra, hogy elgondoljuk, a különbözô filmtípusok milyen módon nyúlhatnak a traumatikus affektushoz.

Nem szokatlan a narratív film fentiek szerinti szúk értelmezése; a szereplő és a cselekmény alapvetô szerepének hangsúlyozása valóban sarkalatos a filmelméleti tanulmányokban évtizedeken át fôszerepet élvező „klasszikus narratív mozi” központi paradigmájában. Ez a paradigma azon a feltételezett hierarchián nyugszik, hogy a film minden esztétikai és affektív dimenziója a narratív események kazuális láncolatát hivatott alátámasztani, amelyet a karakterek céljai hoznak mozgásba. Hasonlóképpen, a dokumentumfilm konvencionális elméleti modelljei a jelentés előállítását privilegizálták, és margóra szorították az affektus múködését. Mindkét fenti közhelyet azonban hosszú évtizedeken keresztül széles körben megkérdôjelezte a filmelmélet, amely úgy tartotta, hogy a filmnek teste van és a film testet öltött tapasztalatot nyújt. [45]

Miriam Hansen a narratív film természetének átfogó és a feltételezett hierarchiát megfordító újragondolását összegezve, a filmnarratíva értelmezésekor a filmnek az érzéki-affektív tapasztalatát állítja a középpontba. Hansen szerint amit „klasszikus narratív filmként” ismertünk meg, az valójában egyfajta „váz, mátrix vagy háló, mely lehetôvé teszi az esztétikai hatások és tapasztalatok sokaságát”. ${ }^{[46]}$ Hasonlóképpen kérdôjelezték meg a „performatív dokumentumfilm” új formái és az affektus szerepérôl és a nézô megélt testérôl szóló új diskurzusok a dokumentumfilmnek a ,józanság diskurzusaként” történó értelmezését, ahol az affektust kizárták a megismerés vágyából. ${ }^{[47]} \mathrm{A}$ film mint önmagából eredôen testté vált és affektív élményként való értelmezése rugalmasabb lehetôségeket kínál arra, hogyan nyúljon a film a traumához. Hansen elmozdul a reprezentáció képekhez kapcsolt kérdéseitôl, és a filmhez mint teljes mértékben „esztétikai” médiumhoz közelít - vagyis mint olyan médiumhoz, amely minden érzéket és érzéken keresztül történô megtapasztalást igénybe vesz. ${ }^{[48]}$ Az affektus a nézốn múlik: ha az affektust viszonyként értjük, akkor ezt a viszonyt a nézố teljes testi mivoltára való tekintettel kell értenünk.

A filmélmény anyagiságára irányuló, a filmélmény testi alapra helyezése mellett érvelô kísérletek több termékeny értelmezést nyitnak meg a film lehetôségeit illetôen, hogy felébressze a „taktilis, érzéki percepciós módot”, ami középponti jelentôségú azt illetően, amit Walter Benjamin mimetikus tapasztalatnak nevezett. ${ }^{[49]}$ Siegfried Kracauer korai filmteoretikus szerint a film 
folyamatosan belekapaszkodik vagy „belenyomódik” ${ }^{[50]}$ a megtestesült tapasztalatba. Sok kortárs filmteoretikus szerint egy film múködésének kulcsa az intenzív testi élmény felkeltésének a képessége, ezáltal a néző bevonzása a filmmel való affektív, mimetikus kapcsolatba, legyen az narratív, dokumentum- vagy kísérleti film.

A film többhangú. Enunciatív stratégiái összetettek: megoszlanak a hang, kép, mozgás, ritmus, tempó és szín megtestesült dimenziói között, amelyek a mozi többhangú médiumát alkotják. Ha a narratívát „vázként” fogjuk fel, rátalálhatunk a narratív film lüktetésére, amely folytonosan lemerül a megtestesült tapasztalat anyagiságába. Ha felfedezzük a test és a narratíva, az anyagiság és a történet virtualitása közötti oda-vissza mozgást, kezdjük megérteni egy újabb rétegét annak a módszernek, amellyel mind a narratív játékfilm, mind a dokumentumfilm be tudja vonni a nézôt, és amelyet nem lehet a karakterizálás mechanizmusaira szúkíteni. Ezek testet öltött, de kódolatlan intenzitások, amelyek búvópatakként, párhuzamos csermelyekként, összefonódó hangokként futnak és hajtják a narratíva rezgéseinek dinamikáját. Ugyanezek a dimenziók mozgatják a kísérleti múveket a traumatikus affektus megidézésekor. Mind a narratív játékfilm, mind a dokumentumfilm képes olyan módokon nyúlni a traumás tapasztalathoz és a poszttraumás emlékhez, hogy igénybe veszik a többhangúság mindezen dimenzióit. Annak elfogadása, hogy az affektus nem redukálható a reprezentációra, nem jelenti, hogy összeegyeztethetetlen a reprezentációval vagy a narratívával; pusztán csak másik kategória.

Ha az egyszerú bináris - narratíva vagy affekus; szemantika vagy szomatika - megközelítés helyett ezeket az intenzitásokat a film olyan dimenzióinak tekintjük, amelyeken keresztül az affektus fokozott érzéki-affektív kölcsönhatásba tudja léptetni a nézôt, megnyílnak a lehetôségek annak feltérképezésére, hogy ezeket az elemeket hogyan lehet alkalmazni a traumás tapasztalattal dolgozó, különböző filmes múfajok egész sorában. Mit jelent ezeknek az affektív elemeknek a szituatív kontextus vázába illesztése? Ha a narratíva keretet biztosít az affektív dimenzió felbukkanásához, mi a kapcsolat a tartalom vezérelte, szereplőfüggố érzelmi elköteleződés és e formátlanabb, cseppfolyós, anyagi affektus között?

Brian Massumi affektussal kapcsolatos munkája hasznos lehet a jelentést hordozó elemek és az ilyen anyagi, megtestesült dimenziók közötti kapcsolatok megértéséhez. ${ }^{[51]}$ Massumi lényegi különbséget tesz az általa az intenzitás logikájaként leírt affektus és az érzelem konvencionális, tartalomfüggő szemantikus kódolása között. Massumi szerint az affektus „e körön kívül van, [...] asszimilálhatatlan" [52] ehhez a tartalomhoz. Massumi azonban komplexebb, nem vagy-vagy kapcsolatot tételez az affektus és a szemantikai tartalom között: „a nyelv nem pusztán ellentéte az intenzitásnak”; a kettô nem összeegyeztethetetlen - míg a nyelvi kifejezés „tompíthatja az intenzitást" [53], arra is képes, hogy rezonáljon a képre, vagy felerôsítse a kép hatását. Ez magával vonja, hogy a narratív struktúrák nem semmisítik meg szükségszerúen az affektust. Két viszonylag autonóm szféraként teszi elgondolhatóvá ooket, amelyek kölcsönhatásba léphetnek egymással, nem pedig hierarchikus a viszonyuk, ahol az egyik uralja a másikat.

Massumi nem egyszerúen egyenlőségjelet tesz az affektus és az érzékelés közé, hanem az affektust 
az egyén saját vitalitásának, a saját elevenségének az érzékeléseként írja le. Mivel ez a tapasztalat különbözô mértékben, de állandóan jelen lévô dimenziója, e modell lehetôvé teszi az affektus és a jelentés „együttes jelenlétként” való elgondolását és a kettő közötti dialektikus feszültség tételezését.

Az együtt létezô, de egymástól különbözô rétegek fenti koncepciója keretet biztosít annak vizsgálatához, hogy a film milyen különbözô módokon hat több, egyidejúleg múködô szinten.

Ha végiggondoljuk, mit jelent ez a filmnézésnek a megértése szempontjából, fel kell ismernünk, hogy a film különbözố típusú tapasztalatokat tud létrehozni: ez lehet különbözô módokon ható, különböző eredményekkel járó elemek keveréke. A múfajokra alapozó - mint a narratív játékfilm és dokumentumfilm kategóriákban gondolkodó - makromodellek képtelenek megragadni azt a finom, cseppfolyós dinamikát, ahogy ez a dialektikus feszültség a film nézôjében múködik, ezért abból sem tudnak sok mindent felfedni, hogyan foglalkozik a film a traumatikus tapasztalattal.

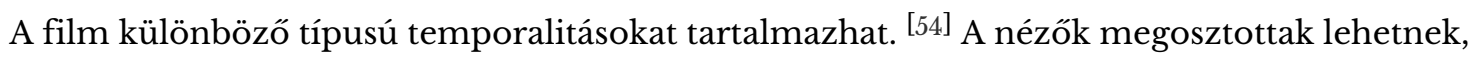
különbözô irányokba tájékozódhatnak. Bár a nézô elmerülhet az ábrázolt diegetikus világ lineáris, kauzális láncolatát temporalitásában, mégis pillanatról pillanatra vonódik be a filmbe. Ez a pillanat performatív jelenében felépülő, igencsak élő folyamat. Megjelenhet a hang, a kameramozdulat, a tér mikroszintjén, és hathat a narratív dimenziók mellett vagy azok ellenében. A testté vált tapasztalat itt más típusú tudás. ${ }^{[55]}$ Az affektust vagy a narratívát elôtérbe helyezô filmi elemek követhetik, váltogathatják egymást, ahogy a film belemerül a nézôi aktivitás blokkjait felépító anyagba és az érzéki-affektív gazdagságot visszatölti a narratívába. A filmi elemek lehetnek egyidejû́ek is, komplex megoldásokkal. A forgatókönyv intenzitása és jelentést hordozó dimenziói ellentmondhatnak egymásnak vagy rezonálhatnak egymással. Az affektus fokozatai váltakozhatnak a film különbözô pontjain. A filmeket kontinuumként kell elképzelnünk, egyik végén a legprózaibb vagy leginkább egyszólamú formáktól - legyenek azok dokumentumfilmek, narratív vagy kísérleti filmek - a másik végén az érzékileg és korporeálisan leggazdagabb, az esztétikailag túláradó és többszólamú megoldásokig.

Bennett arra hívja fel a figyelmet, hogy a múvészet milyen sajátos módokon képes „megtestesíteni és regisztrálni a traumát”. ${ }^{[56]}$ Hasonlóképpen meg kell vizsgálnunk, hogy a narrativizált film megtestesített, érzéki formái milyen kivételes képességeket kínálnak a traumatikus tapasztalat feldolgozásához. Rugalmasabb és kifinomultabb kereteket kell keresnünk annak elemzésére, hogy a film hogyan tud az affektussal dolgozni, és hogyan tudja azt alkalmazni, amikor traumához nyúl. Az elôíró megközelítés helyett termékenyebb, ha kísérletezési folyamatként tekintünk rá, megvizsgáljuk, hogy különböző filmek hogyan oldották ezt meg, és mit tanulhatunk belôlük.

\section{Affektus és performativitás a filmben}

Két film - egy narratív játékfilm és egy dokumentumfilm - kínálkozik, hogy többszólamú dimenzióin keresztül különféle módokon kapcsolódjunk a traumás tapasztalatokhoz. Mindkét film az odafordulás befogadó etikájával kezeli a túlélốk tapasztalatát és a poszttraumás emlékezet 
dinamikáját, de mindkettô csak közvetett módon tanúskodik, és a performatív regisztert alkalmazza: így rázza le a nyelvbe és a reprezentációba vetett realista hitet és provokálja ki a nézôből az affektív, testi elkötelezôdést. Mindkét film elkerüli a traumatikus esemény tényszerú elbeszélését, és mind a túlélô, mint a nézô szemszögéból kérdéseket vet fel a tanúságtétel affektív dinamikájáról.

Bahram Beyzai Bashu, a kis idegen (Bashu, gharibeye koochak, 1986) címú filmje a mozi fenomenológiai képességeit vonultatja fel, hogy elóhívja a poszttraumás tapasztalat természetének megértését. A Bashu fikciós filmként kiemelkedik a traumás emlék természetének - erôszakosan benyomuló jellegének és a szomatikus regisztereken való áthatolásának - világos megértése szempontjából. A film az 1980-as iraki-iráni háború alatt játszódik. Egy iráni kisgyerek alakján keresztül van bemutatva, ami sem az eseményekrôl való távolságtartó reflexiónak, sem a történtek tényszerú elbeszélésének nem hagy teret. A film prológusa megmutatja, ahogy a gyermek családja az iraki bombák tüzében eltûnik a föld alatt, de ezek csak rövid fragmentumok, amelyek elválaszthatatlanná válnak a kisfiú hozzájuk fúzôdố tapasztalatától. A trauma itt a gyermekben maradt üledékként létezik, amelyet robbanások hangja, lángok látványa és mozdulatnyomok váltanak ki; ezek villanásszerúen hozzák elố az elvesztett családot. Bashu a film elsô részében egyáltalán nem képes megszólalni. Mozgékony figura, fut, csapkod, fetreng, csak egy barna csík látszik belóle a sárga kukoricás elôtt, apró test a zöld mezók végtelen terében. Amikor néma jelenléte végre beszédben tör ki, nem a tények objektív előadása szakad fel belôle, hanem szavak, gesztusok formájában kiömló testi áradat. A film fordulópontjánál ez mintha gombnyomásra megnyitná a lehetôséget az újraintegrálására. Ez az áradat mozgásként ömlik ki belőle, a test féktelen ütögetésével, jóval ékesszólóbban, mint amire a szavak képesek lennének. A hang és a ritmus elsöprố érzelemmel töltik meg a pillanatot.

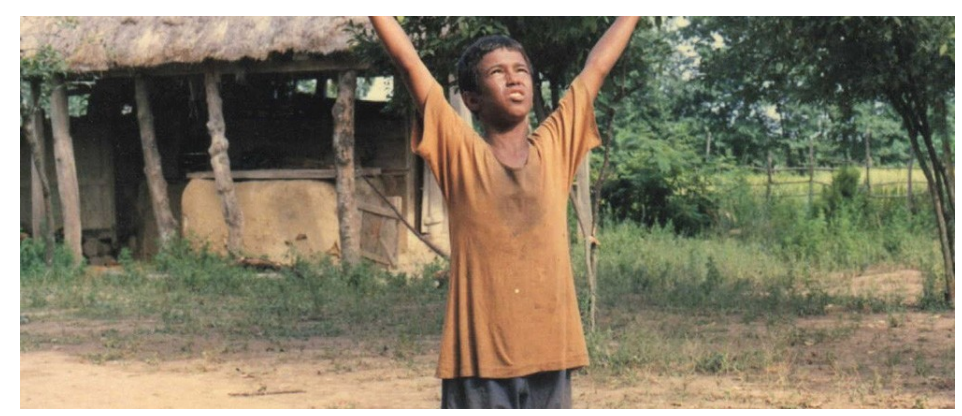

Bashu, a kis idegen (Bahram Beyzai, 1986)

A Bashu ezt a test katarzisán keresztül narrativizálja, de a film olyan intenzitásoknak enged teret, amelyek narratívával ugyanígy nem fejezhetôek ki. Amikor Bashu végre megszólal, a kifejezésmódja minden nyelvi/testi vagy kognitív/affektív különbségtételnek szembeszegül, mintha erre lenne szüksége ahhoz, hogy egyáltalán képes legyen beszélni. Megnyilvánulása fokozott szomatikus kapcsolódást vált ki a nézôbool. A konvencionális narratív megközelítés érvelhet azzal, hogy a film így szorosabb, teljesebb testi kapcsolódást hoz létre a szereplôvel, és ezáltal erôsíti az azonosulás mechanizmusait, azonban itt a gesztus és az ütések performatív energiáján van a hangsúly. A pillanat olyan affektív többletet szabadít fel, amely a „zsigerekig 
hatol”, bekerül a nézô zsigeri emlékezetébe, mégpedig olyan utakon, ami ellenáll a diegézisbe való könnyú asszimilálhatóságnak; a nézôi tapasztalat jelenébe hatol be.

Ezzel nem azt állítom, hogy a szomatikus oldás szorításában vergôdố test minden filmes megjelenítése így múködik, ahelyett, hogy puszta látványosságként kínálná magát. A Bashuban a film energetikai ökonómiája, különösen Bashu elnémult, állandóan mozgásban lévô figurája úgy jut el eddig a pillanatig, hogy a nézố valóban kapcsolatba kerül a testi oldással. Múködik mind a narratíva kognitív, mind a nézô affektív, energetikai dinamikája szintjén. [57]

Ez a film sokkal több egy trauma elbeszélésénél: egyformán szól a különbözôségrôl, az elốtéletrôl és az érzelmi kötôdés megváltó erejérôl. Bashut üldözik a falu kisszerû, bigott lakosai, ahová elkerül, miközben Naii, az ôt befogadó asszony szenvedélyesen védelmezi. Ezek a tényezôk nyilvánvalóan a szereplővel való érzelmi azonosulás szintjén hatnak. A diszkrimináció kérdését nyíltan, párbeszédeken keresztül vizsgálja a film, de a vidéki falu mint helyszín egy újabb szint lehetôségét nyitja meg, ami a szövegkönyvben le van írva, a filmben viszont inkább a hang és a gesztus „enunciatív jelenlétén”, semmint a beszéden keresztül ölt formát. ${ }^{[58]}$ Bashu védelmezôje, Naii szinte animista kapcsolatban létezik együtt a földjein élô madarakkal és vadállatokkal. Ez a kapcsolat úgy mutatkozik meg, hogy fokozottan tudatában van az állatok jelenlétének - képes kiszagolni ôket - és képes kiáltásokkal, horkantásokkal, morgásokkal beszélni velük. Számos rejtély marad a filmben, nem utolsósorban ez a porózus határ az állati és az emberi világ szomatikus kommunikációja között. Bashu szomatikus és vokális megnyilvánulása bizonyos mértékben a filmnek ebbe a szélesebb esztétikai rendszerébe illeszkedik, amely sok elemet elérhetetlenné tesz a nyelv számára, és olyan intenzitásoknak enged teret, amelyek nincsenek világosan definiálva, és nincsen megfelelôjük a verbális nyelvi enunciációban. [59]

A Bashu színtere, a népi kultúra és mítoszok maradványait ôrzô falu és a gyermeknek a narratíva középpontjába helyezése más narratív kontextusba átültethetetlen módon vezetnek a nem nyelvi alakzatok alkalmazásához. A film ugyanakkor megmutatja, hogy egy kibővített narratív repertoár - amely átfogóbban él a kinetikus, vokális, ritmikus, érzéki és narratív kifejezés minden performatív regiszterével és ezek nyelvileg nem könnyen megjeleníthetô tartalmakat megidézô képességével - mélyebbre képes ásni a prózaibb megoldásoknál. Ezek a regiszterek módot kínálnak arra, hogy fenomenológiai szempontból vizsgáljuk a filmet, amely a traumát narratív kontextusba helyezi, így lehetôvé teszi a poszttraumás emlék dinamikájának felismerését, és egyben jelzi a traumás tapasztalat asszimilálhatatlan természetét. Ezzel olyan tér nyilik a szövegben, amely a túlélô-nézôt szólítja meg.

A Puisi Tak Terkuburkan (Garin Nugroho, 1999) címú indonéz filmben is a performatív regiszter jelentôsége merül fel. A stilizált dokumentarista újrajátszás a feltételezett kommunista szimpatizánsok lemészárlásáról emlékezik meg, amely 1965-ban söpört végig az indonéz szigetvilágon. ${ }^{[60]}$ A film Ibrahim Kadir acehi etnikumú túlélô emlékei köré szerveződik, akit azzal vádoltak, hogy kommunista és bebörtönöztek. Kabir egy didong csoport vezetôje, amely énekelt verseket ad elố, hagyományos, közösségi formában. Bár a filmben alapvető fontosságú a közös 
emlékezet melletti elköteleződés, Garin Nugroho, a rendezô elkerüli a történelem testetlen hangját, helyette a didong orális hagyományának érzelmi regisztereivel él. ${ }^{[61]} \mathrm{A}$ film a didong ritmikus dobogásával és éneklésével kezdődik és végződik, amely hívás-válasz szerkezetet alkotva ritmikus áramlatként szövi át a filmet. A film ide-oda ugrik az elmesélés vagy párbeszéd drámai szakaszai és az ének, tánc és taps zenei szakaszai között.

Ez egy messzemenően hibrid film. Igaz, helyenként kifejezetten arra törekszik, hogy megteremtse az azonosulást a szereplôvel, de számtalan további, affektív regisztert alkotó rétege van, amely összetettebbé teszi a nézốk tapasztalatát, hol kizökkent az azonosulás pozíciójából, hol megerôsíti azt. A film teljes mértékben két börtöncella terében játszódik, és nagy hangsúlyt kap benne a várakozó, figyelô, kivégzésre kivezetett fogvatartottak félelme. A film a cella mikrokozmoszán keresztül egyszerre ismer el egy tömeges mértékú, közösségi traumát és fordul empátiával az egyes foglyok felé. Idônként elcsúszik a szentimentalitás irányába, csellóhang szól hangulati elemként. A Puisi Tak Terkuburkan mégis a megrendezettség tudatosságát erôsítô, színházi elôadási hagyományból építkezik: ide tartozik a dráma, az elóadás és a zene számos egymásba fonódó szála között megoszló, önreflexív struktúra; a nyugtalan mobilkamera messzemenôen stilizált alkalmazása; valamint a sưrü, stilizált hangháttér. ${ }^{[62]}$ A teatralitás mérsékli az azonosulást. A cselló idônként inkább a központozás esetlen módja, mint az érzelmi tartalom párhuzama. A film egy sor strukturált ismétlésen halad végig, amelyek erôsítik a struktúra tudatosulását. Az alacsony felbontású videó újabb réteget ad a többihez, amelyek a naturalisztikus filmnézést eltérítik.

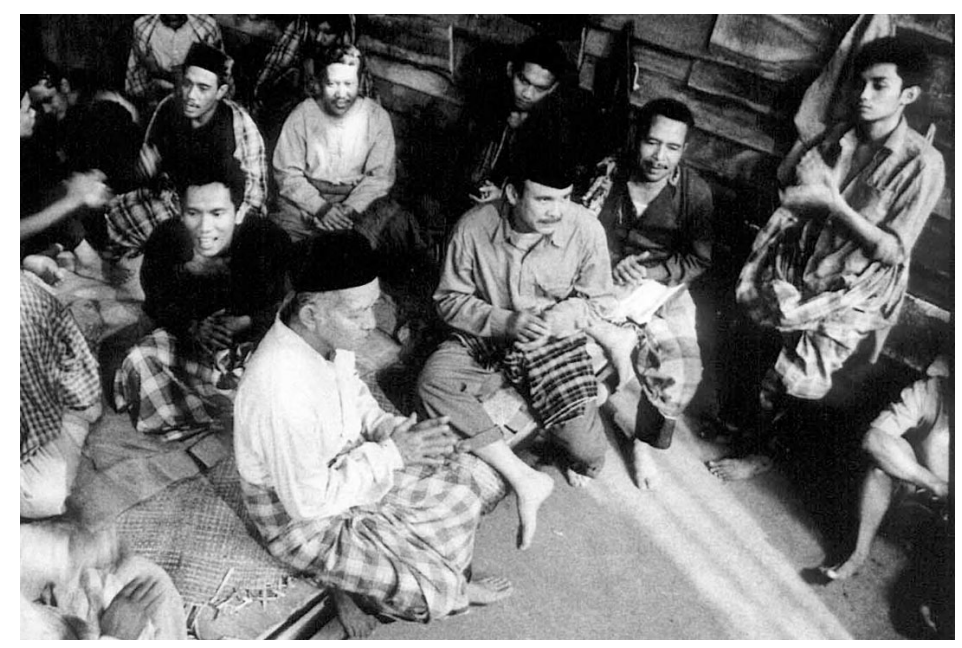

Puisi Tak Terkuburkan (Garin Nugroho, 1999)

Kadir elôadása hasonlóképpen mozog a regiszterek között. A film Kadir egyszerre színész és tanú/túlélố kettôsségét is játékba hozza. Idônként a cellában fogva tartott szereplô; idônként kilép, és önmagává válik. Fekete háttér elôtt egyedül, ezekben a rövid pillanatokban tanúként számol be a történtekról.

Emlékei a filmben nem tényekként, hanem testi emlékként bukkannak fel - mint a testek hangja, „krak, krak, krak”, amikor a fejet a rövid karddal levágják, vagy mint a kéz gesztusa, amely a fejet elválasztja a testtôl. Árnyékban lévô arcából csak egy szeletet látunk a falrésen keresztül, ahogy 
kezével újra és újra imitálja a kard lecsapását. Egy másik rövid töredékben Kadir azt kérdezi, milyen, ha lefejezik az embert, majd kezével eljátssza a fej elválasztását a testtôl, és egyfajta eszelôs nevetésben tör ki, mielốtt a film visszamenekít bennünket az énekhez. Ismét a tanú fekete terében egy csecsemójével együtt meggyilkolt asszonyról beszél, és ahogy az emlék elviselhetetlenné válik, Kadir eljátssza az asszony testének a gördülését, hátat fordít a kamerának és performatív, költői módba vált. Ezek a törések jelzik, hogy az emléket lehetetlen a nyelvi diskurzus megszokott formáival vagy egydimenziós narratív beszámolóként visszaadni. Kadir játéka a gesztusok és a regiszterek közötti váltakozás révén a nézôt affektív eszközökkel eljuttatja odáig, hogy kapcsolódjon az emlék testivé vált minôségéhez, miközben fenntartja a kettôsség fennállásának a tudatát, hogy Kadir egyszerre színész és érintett, a szerepet belülrôl és kívülrôl is betölti. Együtt létezik a közelség és a távolságtartás.

A film a túlélôk iránti törôdés etikáján nyugszik. Igyekszik tisztelettel fordulni a túlélô tapasztalata felé, annak teljességében, és egyben felismeri, hogy a film egy közösségi trauma utóéletét rendezi meg, amelynek számos nézô is részese. A filmkészítők fogékonyak a trauma torzításmentes feldolgozásának igényére, miközben erôszakosságukkal nem veszélyeztetik a nézôk poszttraumatikus sérülékenységét. Nem arra tesznek kísérletet, hogy a gyilkosságok és a vérfürdő minden részletét feltárják. A film integratív, gyógyító, nem pedig történelmi szándékkal fordul a trauma felé. Kadirnak döntési joga van: ahelyett, hogy ösztökélnék, noszogatnák, hogy tényeket és részleteket soroljon, a film megengedi neki, hogy szelektíven szólaljon meg, a maga módján, a saját kifejezésmódjával. A performatív dimenzió teret enged annak, hogy a filmben sokféle különbözô hangot szólaltassanak meg. A film felismeri, hogy a nyelv csak korlátozottan képes az affektív traumatikus tapasztalat visszaadására vagy lefedésére, a megrendezettség pedig megkönnyíti a közönség testi kapcsolódását a tanúságtételhez, miközben nem szimulál teljes vagy mindenre kiterjedô elbeszélést. [63]

\section{Etikai gyakorlat}

Bennett szerint „temporális összeomlás” figyelhetô meg azokban a múvészeti alkotásokban és diskurzusban, amelyek fókuszában „a trauma sokkot kiváltó jelölôre való leegyszerüsítése áll”, nem pedig a poszttraumás emlékezet tartóssága. ${ }^{[64]}$ Bennett szerint fontos annak felismerése, hogy a trauma nem a múlt része, hanem folyamatos szerepet játszik a jelenben. ${ }^{[65]}$ Míg természetesen a traumatikus hatások tartós megmaradásának felismerése alapvetô fontosságú, LaCapra megfogalmazásában, amely e tapasztalatokat a „trauma utóéleteként” írja le, pontosabban megérthetố, hogy a trauma egy pillanat alatt bekövetkezhet - abban a pillanatban, amikor valami áttöri a „pszichikai pajzsot” -,és a végtelenségig megmaradhatnak a hatásai. A trauma egyszerre esemény és állapot. Ugyanakkor tévedés azt feltételezni, hogy az események felsorolása biztosíthatja a traumatikus tapasztalat egyéni hatásainak megértését. Bennett múvészetre irányuló fókusza újabb diszkurzív teret szolgáltat „ahhoz az elköteleződéshez, amely a traumatikus események megélt tapasztalatát ellensúlyként jeleníti meg a közös emlékezet szükséges 
megteremtésével szemben”. [66]

A traumaelmélet célja részben a trauma etikai, politikai dimenzióinak felrajzolása - közösségi és nem csupán egyéni (patológiás) problémaként való értelmezése -, és ennyiben fontos a tanúságtételre és dokumentációra helyezett hangsúly, különösen azáltal, hogy leveszi a szégyen terhét az egyénrôl, és ernyốt kínál, amelyre kivetíthetôk azok a szélesebb társadalmi és politikai erôkkel kapcsolatos ismeretek, melyeknek csapdájába az egyén belekerült. E munka jelentôs részének kifejezett etikai elkötelezettsége ellenére maguk a diskurzus szabta feltételek vezethetnek nemtudáshoz.

A bûntudat, a szégyen és a félelem affektusainak elkülönült fogalmai utat nyitnak az érzelem, így az empatikus azonosulás folyamatai, valamint néhány, potenciálisan traumatikus helyzethez hozzájáruló tényezô megértéséhez; ugyanakkor nem tudnak mit kezdeni „a pszichikai pajzs [affektív] áttörésével”, ami a traumát képezi. Önmagában ez a fogalom minden sajátlagossága ellenére sem fogja át a „pszichikai integritás” testben megnyilvánuló talapzatát. Ennek megközelítéséhez rugalmasabb módokon, nem kategóriákba sorolással kell gondolkodni az affektusról és a testet öltött tapasztalatról.

Hasonló módon, ha azt hisszük, hogy a nyelv képes megragadni vagy kifejezni a traumát, akkor az etikus témakezelés célja - a diskurzusban vagy a múvészi tevékenységben - az események dokumentálása, és a tanúskodás ezt követeli meg. Ha a reprezentáció helyett az enunciáció aktusára helyezzük át a figyelmet, akkor kezdünk rájönni, hogy az enunciáció igazából eleve problémás. Ezek a beszámolók a tudás és az emlékezet bonyolult szövedékébe ágyazódnak. Ha visszafelé fejtünk fel olyan múalkotásokat, amelyek ezt - ha csak részben is - belátják, akkor megfigyelhetjük, hogy egymással szembenálló előfeltevések hogyan alakítják a traumával kapcsolatos további tanúságtételi kísérleteket. Milyen lenne egy olyan film, amely felismerte ezt? Ha a traumáról szóló munkák egyik célja az atrocitás elismerésének integrálása a közös emlékezetbe, akkor be kell látni, hogy a közösség plurális, és megtalálhatóak benne túlélók és nem túlélốk is. Ha a befogadó, a témát etikusan kezelő filmezésbôl és diskurzusból indulunk ki, világossá válik, hogy más megközelítések témakezelési módjukkal hogyan szoríthatják akaratlanul a túlélôket a szélre. Akkor ismerjük fel a többi munkában a hiányosságot, amikor látunk egy befogadó megközelítést.

Ha úgy hisszük, hogy a traumás emlék és tapasztalat lefordítható a nyelvre, akkor ez az ábrázolási mód lesz a kívánatos, és a trauma körüli beszéd normalizálása - annak megszokott mindennapi diskurzusban való megjelenítése - megváltó folyamatnak minôsül. Ha azonban nem fogadjuk el ezt a lefordíthatóságot - ha úgy hisszük, hogy létezik a reprezentáció alól kibúvó mag -, akkor az etikai megközelítésnek teljesen különböznie kell a fentitôl, és többek között ismernie kell az enunciatív aktus affektív dinamikáját. Itt nem előírásról van szó, hanem néhány, az etikai gyakorlatot segítô elvre teszünk javaslatot. Ez a dinamika nem csak a képre vagy a múvészeti alkotásra jellemzó, hanem minden traumával foglalkozó diskurzusra. Itt bármennyire is elsôsorban vizuális kultúráról van szó, a párbeszédnek túl kell mutatnia a képek körén, és a 
szélesebb értelemben vett etikus témakezelést kell megcéloznia.

Fordította Szalai Virág

A fordítást ellenôrizte Török Ervin

[A szöveg forrása: Anne Rutherford: Film, Trauma and the Enunciative Present. In Traumatic

Affect. Newcastle upon Tyne, Cambridge Scholars Publishing, 2013. 80-102.]

\section{Jegyzetek}

1. Ezzel semmiképpen sem hagyjuk figyelmen kívül a disszociációs tapasztalatokat; ezek valójában ugyanannak az éremnek a két oldalát jelentik. A disszociációt elôidézô pszichikai mechanizmus jelzi az ilyenfajta akut jelenlét elviselhetetlenségét.

2. Ez igencsak összetett állítás. Hogyan egyeztethetô össze a trauma egyre szélesebb körben való elterjedtségével? Vajon egyfajta elveszett ártatlanság tragédiáját hirdeti, ami inkább privilégium, mint norma, és ha így van, akkor hogyan definiáljuk a trauma sújtotta emberi szubjektivitásokat? Minden traumához nyúló etikus feldolgozásnak el kell ismernie és tisztelnie kell a „túlélôk” rezilienciáját, talpraesettségét és bátorságát. Másrészrôl, ha a traumapolitika nem képes teljes mértékben megérteni és megfogalmazni a bekövetkezett kár jellegét, és hogy az miért teljességgel elfogadhatatlan - más szóval, ha a nem traumatizált alanyt tekinti mércének -, akkor esélye sem lesz definiálni az atrocitás fogalmát és elmondani, hogy miért kell leleplezni és megelözni.

3. Nyilvánvalóan számos különféle trauma létezik. A „trauma” szó magában foglalja mind a szélsôséges, („küszöbön túli”) túlélô tapasztalatokat, mind a nem szükségszerúen atrocitásból vagy szélsôséges hatásból eredô tapasztalatokat. Míg a trauma természetérôl való elméletalkotáshoz fontos széles értelmében kezelni a fogalmat, ezzel bizonyos mértékben kizárjuk a traumatizáltság különbözô fokozatait elismerô vitákat. Nagyon hasznosnak tartom Dominick LaCapra javaslatát, hogy a fogalmat bizonyos küszöböt meghaladó tapasztalatok számára tartsuk fenn, így ugyanis érdemben meg lehet különböztetni a fizikai vagy pszichikai széteséssel fenyegetổ liminális élményeket és a traumatikus élmények egy élet során felgyúlő általánosabb, „mindennapi” formáját. A „saját megsemmisülésünk fenyegetése” itt inkább az extrém típusú traumákra vonatkozik. LaCapra, Dominick: Writing History, Writing Trauma. Baltimore, Johns Hopkins University Press, 2001.

4. Herman szerint a trauma egyik legfontosabb jellemzője a „kimondhatatlanság”. A szakirodalom vitatja ezt az állitást, én azonban egyetértek vele. Herman, Judith: Trauma és gyógyulás: [az eröszak hatása a családon belüli bántalmazástól a politikai terrorig]. Ford. Kuszing Gábor, Kulcsár Zsuzsanna. Budapest, Háttér, Kávé K., NANE Egyes., 2003.

5. Hálás vagyok Magdalena Zolkosnak ezért a szóképért.

6. Marks, Laura: The Skin of the Film. Durham \& London, Duke University Press, 2000. 141. Marks itt Walter Benjamin és Maurice Merleau-Ponty gondolataira egyaránt reflektál.

7. Soha nem találkozó, egymáshoz konvergáló egyenesek.

8. LaCapra, Dominick: Lanzmann's Shoah: Here There is No Why. Critical Inquiry, 2, 1997. tél, 23.

9. Maga LaCapra Shoshana Felmant említi e tendencia jellegzetes példájaként. Felman, Shoshana - Laub, Dori: Testimony: Crises in Witnessing in Literature, Psychoanalysis, and History. New York, Routledge, 1992.

10. Kaplan, E. Ann: Trauma Culture: The Politics of Terror and Loss in Media and Literature. New Brunswick, NJ, 
Rutgers University Press, 2005. 39.

11. Kaplan részletesen bemutatja az itt megnyilvánuló különbségeket.

12. A tanúskodás körüli ambivalenciát mélységében vizsgálták a fotózsurnalizmus terén. Lásd pl. Sontag, Susan: Regarding the Pain of Others. London, Penguin, 2003.

13. Ez nem azt jelenti, hogy a túlélók folyamatosan áldozati állapotban élnek, de rezilienciájukat érhetik olyan támadások, amelyek felhozzák a traumát a jelenbe. Bennett a múvész Charlotte Delbót idézi, aki úgy magyarázza, hogy különbözô énjei vannak: a jelenlegi énje és az „Auschwitz-énje”. Ezek különböző rétegekként léteznek együtt, de adott körülmények között az „Auschwitz-én” fájdalmasan feltörhet a jelenbe. Bennett, Jill: Emphatic Vision: Affect, Trauma, and Contemporary Art. Stanford, California, Stanford University Press, 2005. 25.

14. Bennett: i.m. 6 .

15. Sontag: Regarding the Pain, 125.

16. Canales, Alejandra: A Silence Full of Things, 2005. URL: http://vimeo.com/3504830 (utolsó megtekintés: 2012. 06. 22.)

17. Nem azt állítjuk, hogy a traumák között „hierarchia” lenne, hanem bizonyos fajta traumák sajátosságára hívjuk fel a figyelmet.

18. Bennett: Emphatic Vision, 22 és a további oldalak.

19. Bennett: i.m. 45 .

20. LaCapra kritikájában nem fejt ki értékítéletet, ugyanakkor tiszteletét fejezi ki Lanzmann általa „mestermúnek” tartott filmjével szemben.

21. LaCapra a traumatikus újraélés folyamatára összpontosít, tehát az ô fókuszában a film létrehozása, nem annak fogadtatása áll, a nézôi szerep kérdését pedig abból a szemszögból vizsgálja, hogy a nézô nem túlélő.

22. Hansen, Miriam: Schindler's List is not Shoah: the Second commandment, Popular Modernism and Public Memory. Critical Inquiry, 22, 1996. tél, 302.

23. A borzalom ábrázolhatatlanságáról lásd pl. i.m. 301.; Sontag: Regarding the Pain és Didi-Huberman, Georges: Images Malgré Tout. Paris, Éditions de Minuit, 2003.

24. Bennett röviden összefoglalja ezt a vitát, miközben Geoffrey Hartmann munkáját idézi az ún. „másodlagos traumatizálódásról”. Bennett: Emphatic Vision, 35. Lásd még Kaplan: Trauma Culture.

25. Lásd Gibbs, Anna: Horrified: Embodied Vision, Media Affect and the Images. In Interrogating the War on Terror. Szerk. Staines, Deborah. London, Cambridge Scholars Publishing, 2007. Gibbs kifejezetten a fotózás és az Abu Graib börtönben elkövetett kínzásokról készült képek kérdéskörével foglalkozik.

26. Semmilyen adatot nem tudok közölni errôl az interjúról, amelyet az ausztrál televízióban láttam valamikor 2010-ben vagy 2011-ben. Ez a pillanat hatott rám, megmaradt az affektív emlékezetemben, minden egyéb részlet törlődött.

27. Az elöadó - maradjon anonim - az ausztrál történelem kora gyarmati történéseirôl beszélt.

28. Bennett így ír: „a tanúvá válás bizonyos értelemben kudarcot vallhat, ha a nézốk olyan körülmények között látják a felkavaró képeket, amelyek egyáltalán nem kényszerítenek tartós bevonódásra”. Bennett: Emphatic Vision, 64.

29. Herman: Trauma and Recovery, 147.

30. Ez az eltérés fontos törésvonalra irányítja rá a figyelmet a traumafilmeknél, interdiszciplináris területről lévén szó.

31. Canales: Silence. 
32. Bennett szerint „az érzékelés emlékezetével dolgozó múvészet [...] nem az eredeti traumát - az érzés okát - akarja képviselni, hanem a poszttraumás emlékezet állapotát vagy tapasztalatát megjeleníteni.

33. Bennett: i. m. 23.

34. Bennett: i. m. 8 .

35. Bennett: i. m. 10. Bennett Brechtet idézi.

36. Bennett: i. m. 23.

37. Bennett: i. m. 23.; 3. Bennett nem tiltja teljesen szereplôk alkalmazását; olyan múalkotásoknak ad hitelt, amelyek „a szereplôt flow-ként”, nem pedig az empatikus azonosulás narrativizált tárgyaiként jelenítik meg.

38. Bennett: i. m. 50.

39. Bennett: i. m. 7; 10. Bennett Maurice Blanchot-t idézi.

40. Bennett: i. m. 24.

41. Bennett: i. m. 21.

42. Bennett: i. m. 31 .

43. Bennett: i. m. 46 és a további oldalak.

44. Bennett: i. m. 7.

45. Lásd pl. Marks: The Skin; Sobchack, Vivien: The Address of the Eye: A Phenomenology of Film Experience. Princeton, Princeton University Press, 1992; és Rutherford, Anne: „What Makes a Film Tick?”: Cinematic Affect, Materiality and Mimetic Innervation. Bern, Peter Lang, 2011.

46. Hansen, Miriam: The Mass Production of the Senses: Classical Cinema as Vernacular Modernism. In Reinventing Film Studies. Szerk. Christine Gledhill és Linda Willliams. London, Arnold, 2000. 339. Magyarul Az érzékletek tömeggyártása: a klasszikus film mint vernakuláris modernizmus. Ford. Füzi Izabella. Apertúra, 2018. tavasz. URL: https://www.apertura.hu/2018/tavasz/hansen-az-erzekletektomeggyartasa-a-klasszikus-film-mint-vernakularis-modernizmus/. Ford. mód.

47. A „performatív dokumentumfilm” Bill Nicholstól ered: Blurred Boundaries: Questions of Meaning in Contemporary Culture. Bloomington \& Indianapolis, Indiana University Press, 1994. E kérdések dokumentumfilmekre vonatkozó részletes kifejtését lásd: Rutherford, Anne: The Poetics of a Potato: Documentary that Gets Under the Skin. Metro, 137, 2003. A ,józanság diskurzusa” kifejezés a befolyásos korai elméleti és gyakorlati dokumentumfilmestôl, John Griersontól származik.

48. Hansen itt arra utal, ahogy Walter Benjamin a görög aisthitikos („,a test beszéde”) szót definiálja.

49. Hansen, Miriam: Benjamin and Cinema: Not a One-Way Street. Critical Inquiry, 25. 2, 1999. tél. Hansen szerint Benjamin fogalomhasználata elkülöníti a mimézis valósághúséghez kötődô felfogásait: „a mimézis az ábrázolás naturalista vagy realista normáin és az ábrázolásnak a valósághoz fưződô meghatározott viszonyán (másolás, tükrözés, hasonlítás) túl olyasfajta gyakorlatként idéződik meg, amely meghaladja az alany-tárgy hagyományos dichotómiáját [...]; olyan kogníciós mód, amely magában foglalja a percepció érzékszervi, szomatikus és taktilis formáit."

50. Hansen, Miriam: With Skin and Hair: Kracauer's Theory of Film, Marseille 1940. Critical Inquiry, $19,1993$. tavasz, 447.

51. Massumi, Brian: The Autonomy of Affect. In Deleuze: A Critical Reader. Szerk. Paul Patton. Oxford \& Cambridge, Massachusetts, Blackwell, 1996.

52. Massumi: i.m. 219-221.

53. Massumi: i.m. 219.

54. Ezek lehetnek a narratív idô, a képernyôidô és az idôtartam. 
55. Bennett modelljében az érzékek felajzása elvezet a gondolathoz. Én itt inkább az „élô gondolat” fogalmára teszek javaslatot - amely benne rejlik a tapasztalatban, nem pedig követi azt.

56. Bennett: Emphatic Vision, 4.

57. A nézôk e pillanatra adott válasza a korábbi tapasztalataik függvényében eltérô: olyan hangon szólal meg, amely belépési pontot kínál a trauma utáni élet ismerôinek, miközben mások számára felépíti a helyzetet.

58. Raquel Schefer rendkívül érdekes - Ruy Guerra Mueda: Memory and Massacre címú filmjével összefüggésben az „enunciatív jelenrōl” írt - munkájának hatására választottam keretként az enunciáció kérdéseit ehhez az esszéhez. Schefer, Raquel: Re-consitutions. On Mueda, Memória e Massacre (Mueda, Memory and Massacre), by Ruy Guerra. Le Journal de La Triennale, 4, 2012. május 18. URL: http://www.latriennale.org/en/lejournal/you-do-not-stand-one-place-watch-masquerade/reconstitutions-mueda-memoria-e-massacre. (Megtekintve 2012. november 1.)

59. Negar Mottahedeh Bashut a rituális perzsa színház egyik formáját képviselő Ta’zieh kontextusában helyezi el. Mottahedeh, Negar: Bahram Bayzai. In Life and Art: The New Iranian Cinema. Szerk. Rose Issa és Sheila Whitaker. London, National Film Theatre, 1999. Peter Chelkowsky szerint a Ta’zieh történetében a szöveg alakult ki legutolsónak: hagyományos formájában a drámát teljes egészében vagy túlnyomórészt zene és ének révén közvetítik. Ez a kontextualizáció utal a performanszhagyomány hatására a Bashu szomatikus és ritmikus narratív szerkezetében. Chelkowsky, Peter: Ritual and Drama in Iran. New York, New York University Press, 1979. URL: http://worldcinemadirectory.co.uk/component/film/?id=986. (Megtekintve 2012. november 25.)

60. Puisi Tak Terkuburkan (angol címe: A Poet: Unconcealed Poetry). A kétmillió embert elpusztító tisztogatás részleteirôl lásd: Griswold, Dierdre: Indonesia 1965: The Second Greatest Crime of the Century. New York, World View Publishers, 1979.

61. A didong alkalmazásának és a film formális stratégiáinak részletes elemzését lásd Rutherford: Poetics and Politics.

62. A film szereplői egy színházi társulat hivatásos tagjai és egyben helybéli acehi falusiak.

63. A gyártási folyamat beszámolók szerint könnyek és gyász között zajlott. A Puisi Tak Terkuburkan SAPFF (Sydney Pacific Film Festival) 2001 sajtócsomagja.

64. Bennett: Emphatic Vision, 65.

65. Bennett: i. m. 40 .

66. Bennett: i. m. 58. Bennett itt a múvész Charlotte Delbo munkájáról ír.

\section{Irodalomjegyzék}

- Bennett, Jill: Emphatic Vision: Affect, Trauma, and Contemporary Art. Stanford, California, Stanford University Press, 2005.

- Canales, Alejandra: A Silence Full of Things, 2005. URL: http://vimeo.com/3504830

- Chelkowsky, Peter: Ritual and Drama in Iran. New York, New York University Press, 1979. URL: http://worldcinemadirectory.co.uk/component/film/?id=986.

- Felman, Shoshana - Laub, Dori: Testimony: Crises in Witnessing in Literature, Psychoanalysis, and History. New York, Routledge, 1992.

- Gibbs, Anna: Horrified: Embodied Vision, Media Affect and the Images. In Interrogating the War on Terror. Szerk. Staines, Deborah. London, Cambridge Scholars Publishing, 2007.

- Griswold, Dierdre: Indonesia 1965: The Second Greatest Crime of the Century. New York, World 
View Publishers, 1979.

- Hansen, Miriam: Benjamin and Cinema: Not a One-Way Street. Critical Inquiry, 25. 2, 1999. tél. https://doi.org/10.1086/448922

- Hansen, Miriam: Schindler's List is not Shoah: the Second commandment, Popular Modernism and Public Memory. Critical Inquiry, 22, 1996. tél.

https://doi.org/10.1086/448792

- Hansen, Miriam: The Mass Production of the Senses: Classical Cinema as Vernacular Modernism. In Reinventing Film Studies. Szerk. Christine Gledhill és Linda Williams. London, Arnold, 2000. 339. Magyarul Az érzékletek tömeggyártása: a klasszikus film mint vernakuláris modernizmus. Ford. Füzi Izabella. Apertúra, 2018. tavasz. URL:

https://www.apertura.hu/2018/tavasz/hansen-az-erzekletek-tomeggyartasa-a-klasszikus-filmmint-vernakularis-modernizmus/

- Hansen, Miriam: With Skin and Hair: Kracauer's Theory of Film, Marseille 1940. Critical Inquiry, 19, 1993. tavasz. https://doi.org/10.1086/448682

- Herman, Judith: Trauma és gyógyulás: [az erốszak hatása a családon belüli bántalmazástól a politikai terrorig]. Ford. Kuszing Gábor, Kulcsár Zsuzsanna. Budapest, Háttér, Kávé K., NANE Egyes., 2003.

- Kaplan, E. Ann: Trauma Culture: The Politics of Terror and Loss in Media and Literature. New Brunswick, NJ, Rutgers University Press, 2005.

- LaCapra, Dominick: Lanzmann's „Shoah”: Here There is No Why. Critical Inquiry, 2, 1997. tél, 23.

https://doi.org/10.1086/448828

- LaCapra, Dominick: Writing History, Writing Trauma. Baltimore, Johns Hopkins University Press, 2001.

- Marks, Laura: The Skin of the Film. Durham \& London, Duke University Press, 2000.

- Massumi, Brian: The Autonomy of Affect. In Deleuze: A Critical Reader. Szerk. Paul Patton. Oxford \& Cambridge, Massachusetts, Blackwell, 1996.

- Mottahedeh, Negar: Bahram Bayzai. In Life and Art: The New Iranian Cinema. Szerk. Rose Issa és Sheila Whitaker. London, National Film Theatre, 1999.

- Nichols, Bill: Blurred Boundaries: Questions of Meaning in Contemporary Culture. Bloomington \& Indianapolis, Indiana University Press, 1994.

• Rutherford, Anne: „What Makes a Film Tick?”: Cinematic Affect, Materiality and Mimetic Innervation. Bern, Peter Lang, 2011. https://doi.org/10.3726/978-3-0351-0256-7

- Rutherford, Anne: The Poetics of a Potato: Documentary that Gets Under the Skin. Metro, 137, 2003.

- Schefer, Raquel: Re-consitutions. On Mueda, Memória e Massacre (Mueda, Memory and Massacre), by Ruy Guerra. Le Journal de La Triennale, 4, 2012. május 18. URL:

http://www.latriennale.org/en/lejournal/you-do-not-stand-one-place-watch-masquerade/reconstitutions-mueda-memoria-e-massacre.

- Sobchack, Vivien: The Address of the Eye: A Phenomenology of Film Experience. Princeton, Princeton University Press, 1992.

https://doi.org/10.1515/9780691213279 
- Sontag, Susan: Regarding the Pain of Others. London, Penguin, 2003. https://doi.org/10.3917/dio.201.0127

\section{Filmográfia}

- Bashu, a kis idegen (Bashu, gharibeye koochak. Bahram Beyzai, 1986)

- Puisi Tak Terkuburkan (Garin Nugroho, 1999)

- Soá (Shoah. Claude Lanzmann, 1985) 
(C) Apertúra, 2020. tavasz | www.apertura.hu

webcím: https://www.apertura.hu/2020/tavasz/rutherford-film-trauma-es-az-enunciativ-jelen/

https://doi.org/10.31176/apertura.2019.15.3.1

\section{Q)opertúro}

